\title{
THE GROWTH OF SEAWEED (KAPPAPHYCUS ALVAREZII) CULTIVATED WITH LONG LINE AND OFF BOTTOM METHOD ON TITA BANDA NEIRA MALUKU COASTAL AREA
}

\author{
Aditya Putra Basir ${ }^{a}$, La Abukena ${ }^{b}$, Amiluddin ${ }^{b}$ \\ a. Student of Sekolah Tinggi Perikanan Hatta Sjahrir Banda Neira, Maluku, Indonesia \\ b. Lecturer of Sekolah Tinggi Perikanan Hatta Sjahrir Banda Neira, Maluku, Indonesia
}

\begin{abstract}
This research aimed to know the growth rate of seaweed (Kappaphycus alvarezii) cultivated by using off bottom method and long line method in coastal waters Tita Dwiwarna Village Banda Central of Maluku. It is expected that this research will provide basic information in business of seaweed cultivation that will be developed. The methods were off bottom method and long line method that consisted of 2 treatments and 3 replications. Material used was mostly a polyethylene rope as long as 10 meters with the diameter size $5 \mathrm{~mm}$ for a mine rope and $3 \mathrm{~mm}$ for a span rope. Initial weight of sea weeds which is tied to a span rope 100 gram. The growth data collection was taken simultaneously with water quality data every week. Data were analyzed by using Cohran test to see homogeneity. The homogeneity data were then analyzed by using t-test to see the different between two treatments. The result of the research has shown that seaweed growth was the highest in off bottom methods which average weight on the seventh week reached 690 gram. While the growth with long line methods reached the average weight on the seventh week reached only 609.4 gram. Therefore, the best growth of the sea weed was represented by off bottom method.
\end{abstract}

Keywords: Growth, Sea weed.

\section{INTRODUCTION}

Banda island is one of areas with high potential of seaweed, if it is supported by an appropriate cultivation techniques, it will increase productivity, expand employment, increase fisherman income, meet the local and international market needs, meet the nutritional needs, maintain the preservation of biological resources in order to be sustainable. To reach a maximum production, it is important to consider some supporting factors, including the use of good quality seaweed, intensive cultivation technique, attention to post-harvest activities and the continuity of production result [1].

Tita coastal is one of coastal area located in Banda which is rich of marine resources. Seaweed is one of them [2]. Yet, the utilization of seaweed in Tita coastal area depends on the nature stocks. Basically, Tita has sloping coastal base with sandy substrate with coral and coral splinter. Seaweed cultivation by off bottom method is basically used on coastal area with coral, sandy based or sand with coral splinter [3].

To compensate for excessive utilization in nature, it is necessary to do various method of cultivation to meet the need of seaweed in certain quantity. To produce high quality seaweed, it is important to consider the cultivation method based on the coastal area characteristic.

This research aims to determine the seaweed growth rate cultivated by long line and off bottom method on Tita coastal area Dwiwarna village Banda Maluku island. The research finding is to be expected to provide information of developing cultivation method in order to

* Corresponding Author.Hp: +6281248023495

E-mail: adityabasir88@gmail.com 
support the seaweed cultivation (Kappaphycus alvarezii) in Banda Island.

\section{MATERIAL AND METHOD}

The research was held in September November 2012 in Tita coastal area, Banda Maluku. The material used was 1800 gram seaweed (Kappaphycus alvarezii). The research method used was experiment with 2 different treatments namely long line method and off bottom method with 3-time repetitions. The initial weight of the seaweed used was 100 gram with $50 \mathrm{~cm}$ spacing.

\subsection{Long line method}

In this action, there were 4 main buoys and 12 supporting buoys. The main buoys were interconnected using $5 \mathrm{~mm}$ polyethylen ropes that it formed $10 \times 5 \mathrm{~m}$ rectangle. $3 \mathrm{~mm}$ polythylen rope with $10 \mathrm{~m}$ length were used as branch tied to main rope which function to tie the seaweed seeds. The supporting buoys were tied to branch rope with $2,5 \mathrm{~m}$ spacing in order to make the seaweed seed remain floating on the water column and not drowning. Each main buoy was completed with ballast to make the longlines stay in its position in case there was strong wind. This action was done on Tita coastal area in $5 \mathrm{~m}$ depth.

\subsection{Off Bottom Method}

In this action, there were 4 wooden pegs used, with $150 \mathrm{~cm}$ length. $1 / 3$ part $(50 \mathrm{~cm})$ of each wooden peg was installed to sea floor. The 5 $\mathrm{mm}$ polythylen rope as the main rope was tied to each wooden peg to form a $10 \times 5 \mathrm{~m}$ rectangle. The distance between the main rope and the sea floor was $30 \mathrm{~cm} .3 \mathrm{~mm}$ polythylen rope with 10 $\mathrm{cm}$ length as the branch rope is tied to the main rope which functioned as a place to tie the seaweed seed. The rope span was $1 \mathrm{~m}$.

\subsection{Collecting Data}

The growth of the seaweed was measured weekly by weighing the weight of the seaweed by using plastic scales with $1 \mathrm{~g}$ accuracy followed by the measurement of environmental quality standards. The coastal environment quality observed includes physic, chemistry, and biology parameters. The physics parameter observed included the current, temperatures and brightness. Temperatures were measured by thermometer, current was measured by stopwatch, plastic ball and rope. Brightness was measured by secchi disc. Chemical parameter was used to observ the salinity and $\mathrm{pH}$, salinity was measured by refractometer. The $\mathrm{pH}$ was measured by $\mathrm{pH}$ indicator. Biology parameter was in the form of parasite biota which was observed visually.

\subsection{Data Analysis}

Measurement of seaweed growth rate uses the following formula [4]:

a. absolute growth rate formula :

Description

$$
\mathrm{Ga}=\frac{\mathrm{M} 2-\mathrm{M} 1}{t 2-t 1}
$$

$\mathrm{Ga} \quad$ : absolute growth rate

M1 : seaweed weight of $1^{\text {st }}$ measurement

M2 : seaweed weight of $2^{\text {nd }}$ measurement

t1 $: 1^{\text {st }}$ weighing duration

t2 $: 2^{\text {nd }}$ weighing duration

b. relative growth formula

$$
\mathrm{Gr}=\frac{1}{N 2} \cdot \frac{(M 2-M 1)}{t 2-t 1}
$$

Description

$$
\begin{array}{ll}
\mathrm{Gr} & : \text { relative growth rate } \\
\mathrm{N} & : \text { total individu } \\
\mathrm{M} 1 & : \text { seaweed weight of } 1^{\text {st }} \text { measurement } \\
\mathrm{M} 2 & : \text { seaweed weight of } 2^{\text {nd }} \text { measurement } \\
\mathrm{t} 1 & : 1^{\text {st }} \text { weighing duration } \\
\mathrm{t} 2 & : 2^{\text {nd }} \text { weighing duration }
\end{array}
$$

\section{c. Homogeneity Test}

To see the homogeneity data, Cohran test is applied :

$$
\mathrm{C}=\frac{S_{2} \operatorname{Max}}{\sum S i_{2}}
$$

d. T-test

To see the growth variety, t-test is used:

$$
\mathrm{t} 0=\frac{M 1-M 2}{S E \mathrm{M} 1-\mathrm{M} 2}
$$




\section{RESULT AND DISSCUSION}

\subsection{Water Quality Measurement}

Water quality does affect the growth of cultivated seaweed. The water quality observed in this research includes salinity, temperatures, $\mathrm{pH}$, brightness, and current rate. K. Alvarezii is susceptible to high salinity fluctuation [2]. Salinity range for $K$. Alvarezii cultivation is 28 $35 \mathrm{ppt}$ [3]. The water temperatures should be around $20^{\circ} \mathrm{C}$ to $28^{\circ} \mathrm{C}$. Too high water temperatures might shrink the seaweed ramification, thus would affect the production quality [4].

In general, marine and coastal water contains relatively stable $\mathrm{pH}$ range. It is caused by the effects of carbonate and bicarbonate salt it contains [5]. Waters with 7-9 $\mathrm{pH}$ belongs to productive waters which are good for seaweed cultivation [2]. The ideal waters brightness for seaweed cultivation is $1 \mathrm{~m}$ above. Turbid waters might block the sun light, so that it could disturb the photosynthesis process [3]. The current rate does affect the cultivated seaweed fertility. The current movement supplies and distributes nutrition needed by seaweed [6]. Yet, overcurrent movement might damage cultivation container and break the thallus seaweed ramification. The result of water quality measurement of Tita coastal Banda Maluku is as follows:

Table 1.

Measurement Result of Water Quality Parameter

\begin{tabular}{lc}
\hline \multicolumn{1}{c}{ Parameter } & Average Score \\
\hline Salinity & $33\left({ }^{\circ} \%_{\mathrm{oo}}\right)$ \\
Temperatures & $28\left({ }^{\circ} \mathrm{C}\right)$ \\
$\mathrm{pH}$ & 7 \\
Brightness & $100(\%)$ \\
Current & $70(\mathrm{Cm} / \mathrm{dtk})$ \\
\hline
\end{tabular}

\subsection{Weekly Growth}

In both treatments, there was always improvement in each week. In long line method, the highest growth reached 294.72 gram/week. In off bottom method, the highest growth reached $316.6 \mathrm{gram} /$ week. In other words, the highest weekly growth happened in off bottom method. The growth result in week VII reached 690 gram for average weight. The result for long line method in week VII only reached 609.4 gram for average weight. This small result is due to the existence of Baronang fish (siganus $s p$ ), seaweed predator, in research location of long line method, while for off bottom method, the existence of other marine plant, such as lamun, can save seaweed from the predator. One of the most violent macro pests which can damage and destroy seaweed is Baronang (Siganus sp) [3].

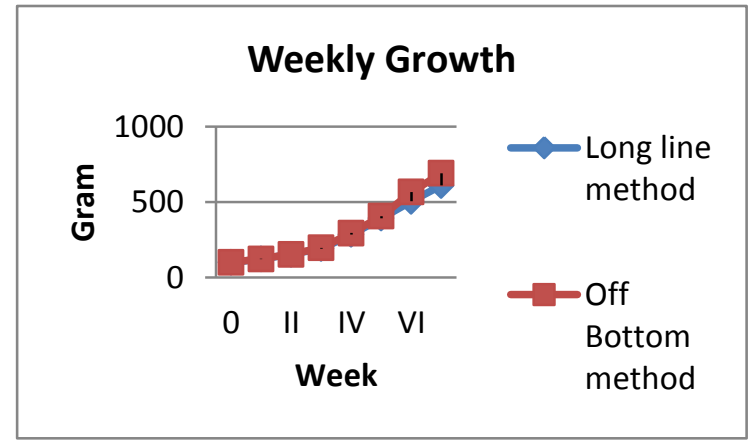

Figure 1. Seaweed Weekly Growth

\subsection{Absolute Growth}

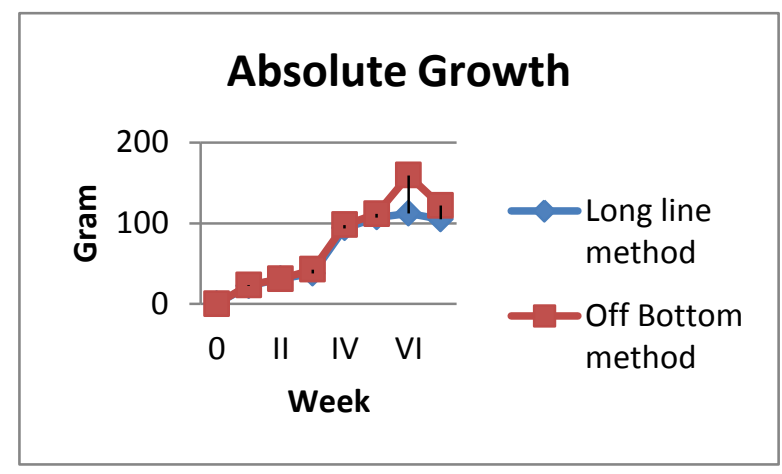

Figure 2. Seaweed Absolute Growth

The absolute growth of long line method observed in week VI, which reached 112.22 gram and the lowest absolute growth happened in week I, reaching 22.2 gram. In off bottom treatment, the highest growth happened in week VI, which reached 159.44 gram and the lowest growth was on week I which reached 2.33 gram.

\subsection{Relative Growth}

Relative growth is presumption in certain period for sample taken from a population in certain observed waters [5]. In long line method, the highest growth reached 1.12 gram, while in off bottom method it reached 1.59 gram. The seaweed growth under long line and off bottom method happened from week I to week VI, it then decreased on week VII. The growth of certain organism will go double or more, then each organisms continue to multiply. This kind of growth will continue to go faster, but it will reach the peak of growth in which that organism cannot 
continue to grow well, the growth is getting slow and will stop in the end [6].

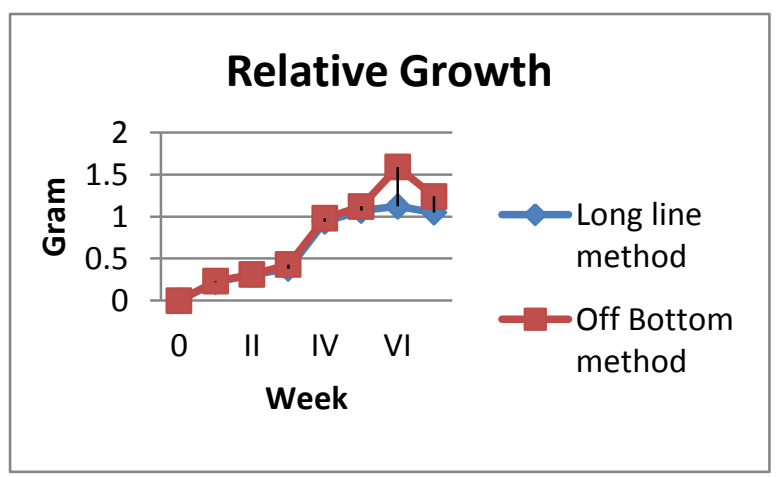

Figure 3. Seaweed Relative Growth

\subsection{Cohran Test and T-test}

The result of homoginity test obtains counted C $(0.504)<\mathrm{C}$ table $(0.734)$. It means both treatments have homogeneous data, it then calculated by t-test. From the t-test calculation, it is obtained the score of $t_{0}$ is $24.639>t$-table either for degree of freedom $5 \%$ with 2,14 value or degree of fredoom $1 \%$ with 2,92 value. This shows that there is a big difference between both treatments.

\section{CONCLUSION}

The growth of seaweed (Kappaphycus alvarezii) which is cultivated by off bottom method on Tita coastal area is better than those which are treated by long line method. Thus, it is recommended to people around Tita coastal area who intend to cultivate the seaweed to use off bottom method as the treatment.

\section{REFERENCE}

[1] L. M. Aslan, Budidaya Rumput Laut, Kanisius, Yoryakarta, Edisi Revisi, $96 \mathrm{Hal}$, 1998.

[2] T. Susilowati, S. Rejeki, E. N. Dewi, Zulfitriani, Pengaruh Kedalaman Terhadap Pertumbuhan Rumput Laut (Eucheuma cottonii) Yang Dibudidayakan Dengan Metode Longline Di Pantai Mlonggo, Kabupaten Jepara, Jurnal Saintek Perikanan, Vol. 8. No. 1, 2012.

[3] Direktorat Jendral Perikanan Budidaya, Petunjuk teknis budidaya rumput laut
Euchema spp. DKP RI, Ditjenkanbud, Jakarta, Hal 41, 2008.

[4] Wa Surni, Pertumbuhan Rumput Laut (Eucheuma cottonii) Pada Kedalaman Air Laut Yang Berbeda Di Dusun Kotania Desa Eti Kecamatan Seram Barat Kabupaten Seram Bagian Barat, Biopendix, 1 (1), 2014.

[5] Djalil, Inventarisasi Jenis-jenis Rumput Laut di Perairan Pantai Tita Kepulauan Banda, PKL, STP Hatta Sjahrir Banda Naira. 2009.

[6] Sunaryat, Pemilihan Lokasi \& Budi Daya Rumput Laut. Makalah Pelatihan INBUDKAD Budi Daya Kerapu di BBL Lampung, Tgl. 24 - 29 Mei, 2004.

[7] C.E. Boyd, Water Quality in Ponds for Aquaculture. Birmingham Publishing Co., Birmingham, Alabama, 454 pp, 1990.

[8] J. T. Anggadiredja, A. Zatnika, H. Purwoto, S. Istini, Rumput Laut. Penerbit Penebar Suadaya. Jakarta, 148 Hal. 2008

[9] A. S. Khouw, Metode dan Analisa Kuantitatif Dalam Bioteknologi Lau, Penerbit Pembelajaran dan Pengembangan Pesisir dan Laut, 2009.

[10] I. N. S. Nuitja, Manajemen Sumberdaya Perairan. IPB. Pres Kampus IPB Taman Kencana, Bogor, 2010.

[11] Effendie, Biologi Perikanan, Yayasan Pustaka Nusantara, 2002. 